\title{
Media Bias: A Corpus-based Linguistic Analysis of Online Iranian Coverage of the Syrian Revolution
}

Algamde, Amaal; Tenbrink, Thora

\section{Open Linguistics}

DOI:

https://doi.org/10.1515/opli-2020-0028

Published: 24/11/2020

Publisher's PDF, also known as Version of record

Cyswllt i'r cyhoeddiad / Link to publication

Dyfyniad o'r fersiwn a gyhoeddwyd / Citation for published version (APA):

Algamde, A., \& Tenbrink, T. (2020). Media Bias: A Corpus-based Linguistic Analysis of Online Iranian Coverage of the Syrian Revolution. Open Linguistics, 6(1), 584-600.

https://doi.org/10.1515/opli-2020-0028

\footnotetext{
Hawliau Cyffredinol / General rights

Copyright and moral rights for the publications made accessible in the public portal are retained by the authors and/or other copyright owners and it is a condition of accessing publications that users recognise and abide by the legal requirements associated with these rights.

- Users may download and print one copy of any publication from the public portal for the purpose of private study or research.

- You may not further distribute the material or use it for any profit-making activity or commercial gain

- You may freely distribute the URL identifying the publication in the public portal ?
}

Take down policy

If you believe that this document breaches copyright please contact us providing details, and we will remove access to the work immediately and investigate your claim. 


\title{
Research Article
}

Amaal Al-Gamde* and Thora Tenbrink

\section{Media Bias: A Corpus-based Linguistic Analysis of Online Iranian Coverage of the Syrian Revolution}

https://doi.org/10.1515/opli-2020-0028

received July 24, 2019; accepted July 06, 2020

\begin{abstract}
This study explores the influence of a government's ideology on linguistic representation in a news agency that characterizes itself as independent. It focuses on the coverage of the Syrian civil war as reported by the Iranian news agency Fars, addressing the discursive constructions of anti-government powers in relevant online reports released between 2013 and 2015. Since the Islamic Republic of Iran was a major regional ally of the Syrian government, we questioned the extent to which ideological independence could be expected during a politically critical time frame. Taking a corpus-based linguistic approach, the study explores the semantic macrostructures representing the opposition as well as the lexical clusters and keywords characterizing the news discourse. The findings indicate that Fars' representation of the Syrian Revolution was, to some extent, biased, despite its claimed independence of the government's political stance. It excluded the Sunni social actors, suppressed the Islamic faction identity of the rebels and depicted the uprising as a war against foreign-backed militants. The rebels were stereotyped in terms of terrorism and non-Syrians. In addition, the analysis reveals Fars' tendency to emphasize the power of the government, depicting it as the defender of the Arab land and foregrounding the discourse of international conspiracy against Syria. The results of this work project the dimension of media bias caused by the underpinning political perspective of media institutions.
\end{abstract}

Keywords: news agency, corpus linguistics, keyword analysis, lexical clusters, semantic macrostructures

\section{Introduction}

The Syrian revolution is a major issue in the Middle East, which has drawn in world powers and received much attention in the international mass media since 2011. Recognizing that media discourse is frequently biased and imbued by the political, economic and social contexts within a country (Fowler 1991), we address the potential influence of a government's political stance on news representation provided by an independent news agency. We focus on Iran as a country that was directly associated with the conflict, and specifically explore the representation of the government opposition, considering the heterogeneous ideological spectrum of armed groups constituting the Syrian opposition. Our key research question can be summed up as follows:

To what extent can a media bias be detected in the representation of the Syrian revolution by Iran's news agency Fars, considering that it declared independence from its government in its own policy statement?

\footnotetext{
* Corresponding author: Amaal Al-Gamde, Department of Foreign Languages, Al Baha University, Al-Baha, Saudi Arabia, e-mail: aalnasher@bu.edu.sa, amaal_moses@yahoo.com

Thora Tenbrink: Department of Linguistics, School of Languages, Literatures and Linguistics, Bangor University, Bangor LL57 2DG, United Kingdom, e-mail: t.tenbrink@bangor.ac.uk
} 
To address this, we focus on two crucial linguistic aspects: first, we isolate the salient keywords that Fars employs to identify the opposition; second, we address the common semantic macrostructures that characterize the representation of anti-government powers.

While most previous literature focus on the language of newspapers, this study undertakes the coverage of an independent news agency that is considered as a non-ideological source of news. Shrivastava (2007) stressed the impartiality of news agencies, citing the Press Commission of India's statement that "As purveyors of news, agencies should not merely keep themselves away from bias and follow strictly the principles of integrity, objectivity and comprehensiveness in the coverage of news, but it should also appear clear to the newspapers and the public that the news agencies are maintaining such a course” (p. 80). Accordingly, tracing the bias in news agencies will be more challenging than tracing it in the press, considering that newspapers include diverse types of news such as editorials, opinion articles and commentaries, which are by nature ideological.

This article is organized into six sections. It starts with an overview of the case study and its background. Section 2 summarizes a review of the previous literature on the discourse studies of the Syrian revolution. Section 3 introduces the analytical corpus-based linguistic framework and the data under investigation. Section 4 provides the analysis and results. Section 5 is on discussion where the questions of the study are answered. Section 6 concludes the study.

\section{Background}

The Syrian revolution is one of several major revolutions that erupted in the Arab countries between 2010 and 2012 under the name of the Arab Spring. In Syria, the uprising was led by Sunni citizens in Daraa 2011. The protesters were often met violently by security forces, police and an Alawite armed faction known as Shabbiha who would beat, arrest, torture and kill protesters (Arimatsu and Choudhury 2014). In response, several teenagers drew graffiti in protest on a school wall in Daraa, saying "Your turn Doctor" in reference to President Bashar Al-Assad (Alsaleh 2015, Asher-Schapiro 2016). One day later, the teenagers were arrested and detained by security forces who then tortured them for weeks. This arrest incited anger amongst the citizenry who carried weapons to protect themselves and their families. As the violence escalated, support for Al-Assad grew more divided. Sectarian groups became involved, and the Sunni majority spoke out against the Shi'ite Alawites who were loyal to the Syrian regime. A cluster of armed groups and international powers was drawn in. Eventually, the uprising turned into a civil war, and the protestors' demands shifted from a call for political reform to overthrowing the President's regime (Rodgers et al. 2016).

Since the Syrian community is composed of different religions, sects and ethnicities, it is important for the current study to understand its social structure to trace the voices that are suppressed or foregrounded in the news coverage. In a statistical report about the religious makeup of Syria that was adapted from BBC News $^{1}$ (2011), the Sunni sect was found to make up the majority of the Syrian population.

Figure 1 indicates that Sunni Kurds, Christians and Alawites are equally distributed, making up roughly $10 \%$ of the Syrian population, respectively, and that the Ismaili and Druze are the least populated religious groups in the Syrian community. All the same, the ruling power is completely centralized within the Alawite minority and controlled by the Ba'ath Party. With reference to ethnicity, Khalifa (2013) noted that Arabs and Kurds were the two largest ethnic groups in Syria, amounting to $80 \%$ and $10 \%$ of the Syrian population, respectively. Although Arabs are distributed throughout the country, the Kurds are primarily located in areas of northeast Syria, including in places of ongoing war, such as Hasakah, Kobani and Afrin.

1 https://www.bbc.co.uk/news/world-middle-east-14520830. 


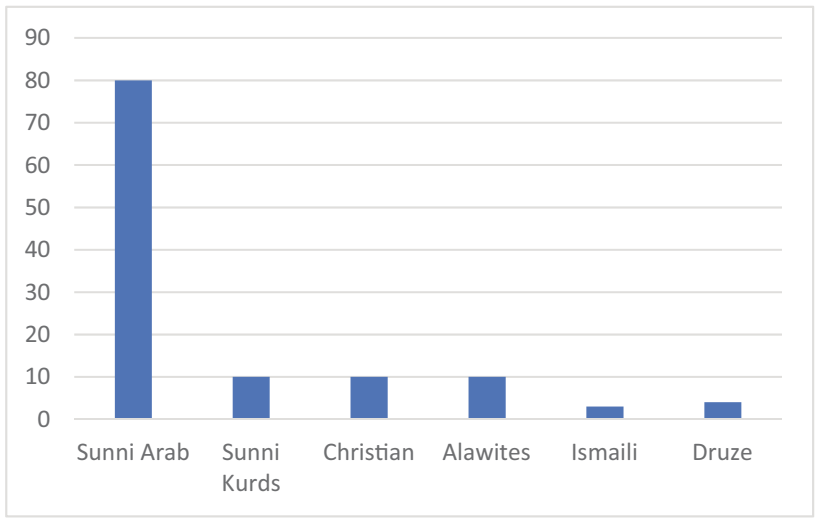

Figure 1: Religion-based ratio of Syrian people.

Interestingly, the armed groups fighting against the Syrian government represent different ideologies. Based on a project accomplished by the Security Assessment in North Africa, the three key ideological authorities in the Syrian conflict are as follows:

- "Secularism (marked by the desire to separate religion from the state);

- Islamism (which entails the ambition to establish an Islamic state in Syria, though not necessarily through violence);

- And Salafi jihadism (which is marked by imperialist Islamist ambitions and takfirism, as practised by AlQaeda)” (Bass 2016, p. 2).

Each of these three ideological authorities is guided by armed forces that impose their dominance and rule over the territories they have gained. Secularism is commonly known as Moderate Opposition, represented by the Free Syrian Army (FSA), who often receive aids from the USA and the Gulf States (Arimatsu and Choudhury 2014). Islamism is a Sunni faction that descended from the Muslim Brotherhood. It was expelled from Syria after revolting against the Syrian government in the 1980s (Porat 2010). The third armed groups, which are Salafi jihadists, are internationally recognized as the most militarily and financially powerful armed opposition group in Syria. According to the Security Assessment in North Africa, Salafi jihadists are commonly involved in the three armed factions of Al-Qaeda, the AlNusra Front and ISIS (Bass 2016). The word Takfirism is an Arabic noun that is derived from the root verb kafara, which means to disbelieve in Allah (God). This radical ideology guides, to a great extent, the radical fighters of ISIL (sometimes ISIS), which refers to the Islamic State of Iraq and Levant. Another powerful defensive front on the Syrian ground includes the Kurdish Defence Units (YPG), which is also known as the People's Protection Units. Its forces are primarily Sunnis and located in northeast Syria.

Understanding the sociopolitical relation between Iran and Syria in this study is crucial to retrieve the ideology underlying the news construction of the government and the rebels. Although the two countries do not share the same language, ethnicities (Arab and Persian) or ideologies (Syria's Ba'ath Party is secular, and Iran is Islamist), their alliance has lasted for more than 30 years (Gelbart 2010). According to Goodarzi (2013), while Iran and Syria have different political interests in the region, their partnership has endured because neither country can fulfil its goals without the strategic support of the other. Goodarzi indicated that Iran's priorities are to regain control over the Persian Gulf, which is currently under the sovereignty of the Arab Gulf States, and to retain the government of Baghdad as a loyal backer of Iran's strategic interests. The Iranian government has also aimed to enhance Iranian pan-Islamism ideologies by supporting Shi'ite Hezbollah in Lebanon and the Hamas movement in Palestine. This is vital, as a passage from Iran to southern Lebanon can only be achieved by way of Syria. According to Goodarzi (2013), President Al-Assad's primary aims for the region were two: first, to remove Israel's sovereignty over the Golan Heights and return it to Arab rule; and second, to gain veto rights over any attempts by the Lebanese government to block or undermine his interests. The Syrian government's ideological goal was 
to promote the Ba'ath Party's pan-Arabism interests in Arab countries. It is worth mentioning that Iran and Syria share the same enemies and similar anti-Americanism and anti-Zionism foreign policies (Gelbart 2010, p. 36).

\subsection{Literature on the Syrian revolution}

Significant literature has used corpus linguistic approaches to investigate critical issues such as the stereotypes of Muslim representation in Western media (Baker et al. 2012, 2013, Richardson 2004, Alharbi 2012), power abuse in different problematic areas, such as immigration, asylum seeker issue and violence against women (Baker and McEnery 2005, Santaemilia and Maruenda 2014) to provide reliable results based on a larger size of data, which minimize subjective analysis. However, the representation of Arab Spring has received little attention in this research tradition, despite the fact that it is the most significant event that has taken place in the Middle East since 2010. In the following, we outline a range of studies in different academic fields that addressed the Syrian revolutions from various other perspectives.

Within the paradigm of critical discourse analysis (CDA), a number of significant studies have addressed the Syrian conflict mostly with a focus on comparing Arab and Western media. For instance, Akkerhuis (2013) used the CDA approach to compare articles released by BBC and CNN, as Western news sources on the one hand, and Al-Arabia and Al-Jazeera as Arabic news outlets on the other, to examine the representation of various uprising issues, among which are the Daraa unrest in Syria and the use of chemical weapons against the rebels. The author found that the four news outlets gave polarized representations, indicating a discourse pattern of supporting the opposition and incriminating the government's atrocities, although each source had a different focus. While BBC's focus mainly revolved around the accusation against Assad's forces for using chemical weapons, CNN was intensifying the coverage around the possible reaction of the US against the Syrian government. Al-Arabia, on the other hand, focused on the role of Hezbollah in supporting Assad and using chemical weapons while AlJazeera's main argument involved the international community's response towards the use of chemical weapons. Accordingly, the four news sources showed similar polarized representations, portraying Assad's government negatively while depicting the opposing side positively.

The same pattern of discourse was revealed by Afzal and Harun's (2015) study of the portrayal of Syrian and Libyan uprisings between 2011 and 2012 in two sets of newspapers: the Arab News, published in Saudi Arabia, and The News International of Pakistan. They examined the effect of their ideological perspectives on public opinion in relation to the content they conveyed. The study revealed a sense of "evaluated belief" in characterizing the authorities in Libya and Syria (p. 243). It relied heavily on the lexical choices and referential strategies used by the newspapers to represent Qaddafi and al-Assad. The findings pointed to strongly negative representations of the two presidents and their brutal actions against protestors. Gaddafi, for instance, was described as "a liar," "more deluded than the Serbian leader" and as an "intolerant regime" (p. 250). Assad was negatively defined as well, as "brutal," bloody" and a "death machine” (p. 250).

Following the same categorization scheme of analysis, Ali and Omar (2016) examined the discursive patterns in the reporting of the intervention of Russian forces in Syria during the current civil war. They employed Halliday's transitivity model to examine the headlines and the leads of CNN and RT (i.e. the Russia Today news network) coverage of the Russian intervention. The study examined the ideology and news production processes in relation to political institutions in the US and Russia. The findings showed that the two news outlets shaped the same event differently, in accordance with the political stance of their respective countries. RT structured the air force intervention as a positive step towards "fighting terrorism and paving the way for a peaceful settlement” (p. 153), while CNN represented the Russian intervention negatively as a destructive power that left no safe place for civilians. The study indicated that the linguistic patterns used in the coverage fell into two main categories: the positive "self" representation and the negative "other" representation. 
Examining the editorials in newspapers was the focus of Amin and Jalilifar's (2013) study. Van Dijk (1996) pointed out that editorials are the pedestals upon which the ideological perspective of the newspapers is expressed. For the purpose of revealing the impact of the newspapers' ideological perspective on news representation, the authors investigated the depiction of the Syrian civil war across three Middle East newspapers, namely, Tehran Times, Today Zaman and Arab News, published in Iran, Turkey and Saudi Arabia, respectively. The findings showed that Arab News and Today Zaman had legitimized the opposition and delegitimized the Syrian government and its supporters by foregrounding the political agenda of Russian military interference and Assad's oppression against his people. In addition, Saudi and Turkish editorials downplayed western interference in the Syrian civil war. Tehran Times' representation, on the other hand, was totally the opposite. It demonized the rebels and their backers while strongly supporting and legitimizing the Syrian government.

The ideological perspectivization of the news media in western newspapers was also examined. Shojaei et al. (2013) investigated the presentation of Syrian crisis, Iranian sanctions and Iranian nuclear program in the headlines and leads of leading UK and US newspapers, among which are the Independent and The Guardian from UK and The New York Times and Washington Post from the US. The study focused on the lexical choices, ideological moves and the patterns of collocates to examine "how linguistic tools can carry ideological traits in their discoursal properties resulting in misrepresentation" of the three cases mentioned above (p. 858). With reference to the findings on the first case of the Syrian crisis, the study concluded that Western newspapers (both UK and US) predominantly passivated the Syrian government as an accused, criminal and guilty social actor, while activating Western politicians as vital social actors, taking on the role of "sayer and sensor" in condemning, criminalizing and threatening the Syrian government.

Campanella (2017) studied the refugee crisis as represented by two Western news media, Fox News and $C N N$, using content analysis. The findings showed huge discrepancies in their coverage. The author attributed the different representation to the political agenda to which each news source adheres, concluding that Fox News "catered mostly to Republican Party consumers" (p. 34), while CNN presented numerous views and voices that defend and sympathize with refugees and challenge the Republican views.

In contrast to these comparative studies, our current contribution goes beyond the common template of Arab versus Western perspective. It provides a Persian perspective, which also yields more insight on a rival Islamic ideology, Shia. This is important because all of the Arab news coverage studied previously represents a Sunni perspective. Thus, it can be concluded that the representations of the Syrian revolution, within the respective comparative frames (in the previous studies), are typically similar. They tend to support the political stance of the opposition and convey the conflict from the government's victims' perspective, which corresponds to the ideological binary image of self-positive versus other negative representations. This might be attributed to the fact that the Arab and Western media they addressed (representing the US and the European league, except Russia) hold the same political stance towards the Syrian revolution. In contrast, this study addressed the Iranian perspective and also examined a different kind of data source, namely, derived from an independent news agency's coverage.

In the context of the Arab revolutions, Iran (as a Persian country) played a pivotal role politically and militarily. The strategic relationship between the two countries had been established early, since 1980, when Syria backed Iran in its 8-year war against Iraq, between 1980 and 1988. This mutual military and financial support was revived at the beginning of the Syrian revolution, in March 2011, by sending Iranian forces and providing training and "logistical support" to the Syrian army (Pantucci and Tabrizi 2016). Iran is considered the sole threatening power to the Arab world in the Middle East and the regional force loyal to the Syrian regime. Furthermore, it shares the same Islamic sectarian orientation with the dynastic ruling family of Syria. Therefore, the perspective offered in this study, with its focus on the news coverage of the Iranian Islamic Republic, is genuinely different from the Arab-centred studies seen in the literature so far. 


\subsection{Methodology and data}

The primary research methodology employed in this study is a corpus-based linguistic approach. We searched for highly frequent linguistic patterns (i.e. recurrent clusters of certain sets of lexical choices) by using corpus analytical tools, to determine common discourses and the roles of the recurrent patterns in revealing the different aspects of news representations. The software AntConc by Anthony (2014) was used to investigate keywords, lexical clusters and their concordances to draw up the dominant semantic macrostructures of the social actors involved in the conflict. The keyword is an important analytical tool utilized to reveal the aboutness alternatively of the thematic frame of a text, on the one hand, and the characteristics of the writing style on the other (Scott and Tribble 2006). The saliency of the keywords' output was derived using the log likelihood statistical measurement to spot significant variations in the lexical frequencies in the target corpus through a comparison with the reference corpus.

The analysis of semantic macrostructure is an important notion in discourse analysis introduced by van Dijk (1985). The term refers to the overall thematic reference or structure of a discourse. Van Dijk (1985, p. 107) states that semantic macrostructure is the overall meaning that "formalizes the theme or the topic of the discourse as a whole" or the semantic meaning that a text or a discourse conveys by their propositions or titles. The notion of semantic macrostructure serves to create a sense of global semantic cohesion in a text or a discourse (Van Dijk 2013). At this level of analysis, the thematic structure is identified by tracing the frequent lexical cluster's patterns of the keywords denoting the opposition social actors and their semantic references in their concordance lines.

The data for this study are a specifically constructed specialized corpus that contains over 5,96,000 words collected from the official website of Fars news agency. ${ }^{2}$ It includes only news reports issued between 2013 and 2015. The choice of an online news agency's reports was made to meet the study's overarching aim of investigating media bias, considering the agency's key role in determining and distributing the news to other news outlets.

\subsubsection{The Fars news agency}

The process of determining appropriate online news sources (newspapers or news agencies) to utilize as data sources initially focused on the following key criteria. First, the selected news source should be national but also represent the Islamic Republic of Iran internationally. Second, the focus of the reporting should place a greater emphasis on political events than social or economic issues. Third, the news media should be available in English. After the application of these three criteria, eight potential news media sources emerged: Iran Daily, Iran Herald, Iran News Daily, NCRI News (National Council of Resistance of Iran), Tehran Times Daily, Kayhan, The Iran Project and Fars. The first six sources are all online newspapers, whereas the final two are online news agencies. All typically produce reports that are approximately three to four paragraphs in length.

A further key consideration was raised upon closer examination, specifically that most of the cyber archives of online newspapers only retain records for up to 1 year, and the Iran Herald's archive contains only 30 days of articles. Furthermore, the archived records can only be accessed using the websites' search engines, as there is no separate archive icon available. The exception is the Tehran Times Daily, which has a systematic archive containing volumes dating back to 1998. Unfortunately, however, the years 2012, 2013 and 2014 are missing, and there are no accessible records from that period. In addition, it was not possible to procure an institutional subscription to any of the newspapers, as no contact details are provided at their official websites.

By contrast, the archive coverage for the two online news agencies, The Iran Project and Fars, dates back further. Both agencies keep news records for 3 years, which fits the limitations of the study's data

2 Fars, www.farsnews.com. 
collection period. As a result, the decision was made to select an online news agency as the data source for the study. However, The Iran Project was excluded due to its alignment with the Iranian government, as declared at its official website, which states that "Everything is issued independently, however not in [any] way causing reprimand from the Iranian government” (“About us," Iran Project). ${ }^{3}$

Accordingly, the decision was made to concentrate on the reports broadcasted by Fars news agency, which was established in 2003. According to The Washington Times, the news agency of Fars is considered an official or semi-official Iranian news website worldwide ("Fars News Agency," n.d.). ${ }^{4}$ Fars stated in its official website that:

Fars News Agency (FNA) is Iran's leading independent news agency covering a wide variety of subjects in different, political, economic, cultural, social, legal, sports, military and other areas with the most up-to-date, independent, unbiased and reliable news and reports in Persian and English (“About us”, Fars). ${ }^{5}$

Furthermore, the website is issued in four international languages, including Arabic, English, Turkish and Persian, which makes it worthy of consideration. In addition, the potential readership of Fars is estimated as 4,643,452 per month according to the statistics given by SimilarWeb, ${ }^{6}$ targeting audiences of different nations and ethnicities, Arab, Persian, Turkish and Western communities. It is important to mention that Fars adheres to anonymity; therefore, its reporters are rarely named or credited on its reports.

\subsection{Analysis and results}

To decode the ideology and the possible bias of the news agency under investigation, the study examines the discursive constructions of anti-government powers involved. The analysis moves from the insights of keywords and lexical clusters' patterns to an elucidation of the themes allocated to each side. Accordingly, positive and negative representations are explicated in relation to the agency's ideological mode. It is worth mentioning that the relationship between language and ideology is enacted through the selection of certain lexical items over other linguistic choices (Van Dijk 1995). Therefore, the way people are identified "can have significant impact on the way in which they are viewed" (Richardson 2007, p. 49). Using the keyword analytical tool, Table 1 shows the first 20 most frequent keywords in the Fars corpus. ${ }^{7}$ The list excludes (i) function words such as articles and prepositions, as they do not convey content of relevance for current purposes, and (ii) words denoting the source of the report, such as Tehran and FNA (the acronym for the Fars News Agency).

Table 1 shows a definite set of lexical choices that identify the anti-government fighters such as terrorists, militants, ISIL, Takfiri and groups. These choices have received high keyness scores ranked 1st, 3rd, 4th, 6th and 10th, respectively. The fact that these lexical choices appear in the list of the top 10 most frequent keywords indicates that the anti-government side of the conflict is a pivotal topic in the coverage and expressed in mostly negative terms (such as terrorists and militants).

To determine the scope of the aboutness related to these keywords, the lexical clusters of each keyword are examined within a three-word span size. Then the concordance lines of the most frequent lexical clusters are investigated to reveal their semantic macrostructures. The following subsections provide a concise analysis of each keyword used to refer to the anti-government social actors ordered according to their saliency.

3 https://theiranproject.com/about/.

$4 \mathrm{https}$ ://www.washingtontimes.com/topics/fars-news-agency/.

5 https://en.farsnews.com/Aboutus.aspx.

6 https://www.crunchbase.com/organization/fars-news-agency\#section-web-traffic-by-similarweb.

7 For the purposes of keyword analysis, UK Reuters' coverage of the same conflict served as a reference corpus for this study. 
Table 1: Top 20 keywords in Fars

\begin{tabular}{lccl}
\hline No. & Frequency & Keyness score & Keywords \\
\hline 1 & 5,214 & $7,565.550$ & Terrorists \\
2 & 7,144 & $5,730.869$ & Army \\
3 & 4,398 & $5,135.191$ & Militants \\
4 & 3,691 & $4,690.725$ & Isil \\
5 & 2,380 & $3,360.138$ & Countryside \\
6 & 1,876 & $3,103.147$ & Takfiri \\
7 & 2,453 & $2,945.787$ & Terrorist \\
8 & 2,472 & $2,145.345$ & Province \\
9 & 1,358 & $1,505.100$ & Destroyed \\
10 & 2,690 & $1,481.529$ & Groups \\
11 & 1,263 & $1,400.047$ & Operations \\
12 & 1,244 & $1,397.150$ & Positions \\
13 & 756 & $1,226.318$ & Meantime \\
14 & 682 & $1,147.275$ & Lattakia \\
15 & 8,155 & $1,109.624$ & Syrian \\
16 & 1,306 & $1,050.990$ & Number \\
17 & 757 & $1,036.497$ & Injured \\
18 & 3,044 & $1,011.887$ & Killed \\
19 & 1,222 & 967.909 & Heavy \\
20 & 630 & 934.243 & Daraa \\
\hline
\end{tabular}

\subsection{Terrorists}

The theme of security threats is the prevailing semantic macrostructure that Fars uses to introduce the anti-government fighters. The identity of the anti-government SAs is depicted in a single frame, which is criminality, using different lexical choices. Therefore, the lexical clusters of terrorists, militants and ISIL show fairly similar lexical patterns, which inform the radical views of Fars against the rebels. Figure 2 shows the most frequent lexical patterns associated with terrorists.

The recurrent patterns above link terrorists to specific names, such as ISIL (391 occurrences), Takfir (309 occurrences) and Nusra (125 occurrences). Other patterns associate terrorists with numbers or quantity, such as number (165 occurrences), tens (134 occurrences) and scores (81 occurrences). There are also some patterns which depict terrorists as supported groups, such as foreign-backed (73 occurrences), and as confronted groups represented by the prepositional phrase against the terrorists (57 occurrences). In addition, the figure shows two prepositional phrases: of the terrorists (206 occurrences) and of Takfiri terrorists (124 occurrences). An examination of the concordances of these phrases reveals that the two patterns are used to depict terrorists as passivated participants who are killed, injured and destroyed by government forces.

Another concept that the frequent lexical clusters of the keyword terrorist reveal is the concept of quantity. This concept is clearly emphasized throughout various clusters, such as number, tens, scores and dozens, in lines 4, 5, 12 and 16 (Figure 3). The quantification of terrorists is linked to losses in ammunition, hideouts and fighters that terrorists have sustained from the government army. The following figure projects a few concordance lines of dozens.

The figure shows a fixed pattern of killing dozens of terrorists, which comes in an active construction where the Syrian army is agentialized as the actor as demonstrated in lines 6, 8, 9, 13 and 15, while the passive form depicts the dozens of terrorists as being killed by the internal infighting among the antigovernment armed groups themselves. The concordances also show that passivization is very often used to construe victims rather than victimizers.

In addition, looking at the lexical choices that are clustered with terrorist, one can realize that they are politically motivated (see ISIL, Al-Qaeda and Al-Nusra in Figure 2). These lexical choices demonstrate a 


\begin{tabular}{|c|c|c|c|}
\hline $\begin{array}{l}\text { Total No } \\
\text { Rank }\end{array}$ & $\begin{array}{l}\text { of Clus } \\
\text { Freq }\end{array}$ & $\begin{array}{l}\text { Types: } \\
\text { Range }\end{array}$ & Total No. of Cluster Token \\
\hline 7 & 397 & 202 & the isill terrorists \\
\hline 2 & 309 & 177 & the takfiri terrorists \\
\hline 3 & 206 & 142 & of the terrorists \\
\hline 4 & 765 & 707 & number of terrorists \\
\hline 5 & 134 & 708 & terns of terrorists \\
\hline 6 & 128 & 95 & isil takfiri terrorists \\
\hline 7 & 125 & 77 & nusra front terrorists \\
\hline 8 & 124 & 87 & of takfiri terrorists \\
\hline 9 & 104 & 77 & al-nusra terrorists \\
\hline 10 & 98 & 67 & of isil terrorists \\
\hline 17 & 87 & 57 & group of terrorists \\
\hline 12 & 81 & 62 & scores of terrorists \\
\hline 13 & 73 & 66 & foreign-backed terrorists \\
\hline 74 & 55 & 49 & that the terrorists \\
\hline 15 & 51 & 44 & gangs and terrorists \\
\hline 16 & 50 & 44 & dozens of terrorists \\
\hline 17 & 50 & 38 & on the terrorists \\
\hline 18 & 40 & 32 & writh the terrorists \\
\hline 19 & 39 & 33 & against the terrorists \\
\hline 20 & 35 & 31 & by the terrorists \\
\hline 21 & 32 & 30 & from the terrorists \\
\hline 22 & 29 & 28 & force destroyed terrorists \\
\hline 23 & 28 & 27 & destroyed the terrorists \\
\hline 24 & 28 & 24 & of foreign terrorists \\
\hline 25 & 28 & 23 & the dead terrorists \\
\hline 26 & 25 & 22 & for the terrorists \\
\hline 277 & 24 & 24 & to the terrorists \\
\hline
\end{tabular}

Figure 2: Lexical clusters of terrorists.

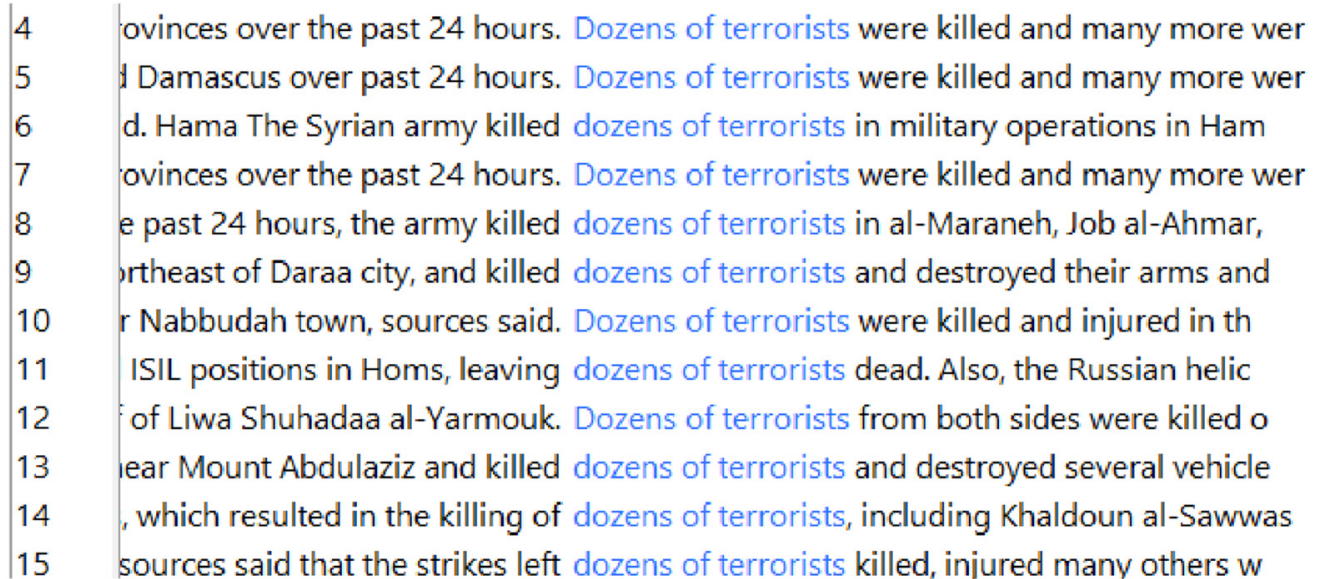

Figure 3: Concordance lines of dozen.

clear classification of the anti-government SAs according to the affiliates they belong to. They are not protestors, rebels, or civilians but fighters and gangs who are well armed and politically organized and foreign backed. Other lexical items are religiously motivated, as in Takfiri. This lexis semantically denotes belief and religion. However, pragmatically, it implies radicalism and violence, consider the following example.

People continued their protests against the Takfiri terrorists in Eastern Ghouta for the fourth consecutive day on Tuesday. On Friday, People poured to the streets of the town of Hamouriya in Eastern Ghouta and rallied against the presence of 
terrorist groups in their town (Fars, 583).

The Observatory's Rami Abdel Rahman said Naameh was likely to have been detained because of his recent criticizing statements against the brutal acts of extremist militants (Fars, 534).

The two excerpts emphasize the danger of those religiously incited militants by describing them as committing brutal acts and detaining people who criticize them. The public stance is evident in rejecting the existence of those radical people by railing against them. The use of the metaphor poured is also important; it suggests a plethora in the number of civilians protesting against those extremists. These lexical choices support each other to enhance the discourse prosody of threat and riots.

\subsection{Militants}

Both militants and terrorists facilitate a negative identification of the rebels and denote an explicit danger. The lexical clusters of militants reveal another emphasis on the theme of threatening power, which is encoded in the nomination of the armed groups as demonstrated in Figure 4.

The salient patterns in Figure 4 are those that frame the identity of the militants as based on belonging to illegal, notorious armed groups, such as ISIL (94 occurrences), al-Qaeda-linked militants (34 occurrences) and Nusra front militant (30 occurrences). These lexical patterns depict the anti-government fighters as organized cells of terrorism using globally recognized names for terrorist organization. Such representation suppresses the role of the Syrian rebels who played a pivotal part in the revolution and by whom the FSA and the Opposition were formed. Figure 4 describes militants as being militarily reinforced, as in foreign-backed militants (272 occurrences), supporting the militants (65 occurrences), of arming militants (61 occurrences) and backed Takfiri militants (58 occurrences).

This sort of recurrent representation emphasizes the theme of allied Western support of the rebels. The militants are introduced as backed, armed and supported by the foreign powers. Specifically, the use of the lexical choice foreign to refer to the Western power has an evaluative meaning, which implies a sense of otherness. Reisigl and Wodak (2001) indicated that as a lexical choice, the term foreigners conveys negative predicational qualities, which inform a hostile perspective that depicts the SAs within the binary representation of victims and criminals. This perspective indicates that the representation of the rebels' allies conforms to the negativity of the anti-government fighters' representation. In addition, the semantic macrostructure of quantification is also evident in the patterns of lexical clusters centred on militants.

Furthermore, militants are described as the agents of the crimes committed against civilians, as exemplified by the pattern of by the militants ( 49 occurrences). Among the semantic environments in

\begin{tabular}{|c|c|c|c|c|}
\hline $\begin{array}{l}\text { Total No. } \\
\text { Rank }\end{array}$ & $\begin{array}{l}\text { of Cluster } \\
\text { Freq }\end{array}$ & $\begin{array}{l}\text { Types } \\
\text { Range }\end{array}$ & Total No of Cluster Tokens & 4398 \\
\hline 1 & 298 & 182 & of the militants & \\
\hline 2 & 272 & 184 & foreign-backed militants & \\
\hline 3 & 232 & 132 & the takfiri militants & \\
\hline 4 & 213 & 123 & number of militants & \\
\hline 5 & 96 & 83 & tens of militants & \\
\hline 6 & 94 & 69 & the isill militants & \\
\hline 7 & 69 & 56 & of takfiri militants & \\
\hline 8 & 68 & 53 & scores of militants & \\
\hline 9 & 65 & 59 & supporting the militants & \\
\hline 10 & 58 & 55 & backed takfiri militants & \\
\hline 11 & 55 & 46 & on the militants & \\
\hline 12 & 49 & 44 & by the militants & \\
\hline 13 & 41 & 28 & units targeted millitants & \\
\hline 14 & 40 & 38 & against the militants & \\
\hline 15 & 40 & 34 & operations against militants & \\
\hline
\end{tabular}

Figure 4: Lexical clusters of militants. 
which this phrase repeatedly exists are the following: Chemical attack was carried out by the militants, massive raids by the militants and Lattikia was attacked by the militants. It is worth mentioning that Lattikia had been assigned as the capital of Alawites during the French Mandate in Syria, yet the rate of Alawites in Lattikia residents was not clearly growing. However, when Hafiz al-Asaad subsequently became the president of Syria after his military coup in the 1960s, the inflow of Alawites increased until they formed the majority population in the city (Goldsmith 2015). Therefore, the reference to Lattikia in this pattern is ideologically significant. It implicitly conveys that militants are only targeting the Alawites' populated cities, thus hinting indirectly at the sectarian identity of the militants, on the one hand, and serving to distance the Syrian government from responsibility for the recurrent assaults against civilians in Lattikia on the other.

The concordances also reveal that the representation of the militants is highly pertinent to the Salafi Jihadist armed groups, such as Al-Qaeda and ISIL, who are known for their fighting skills due to their prolonged history of armed conflicts; however, this representation is juxtaposed with the military reactions of Assad's forces against them, which serves to tone down their power before the government forces.

\subsection{ISIL}

The representation of the rebels moves from assimilating them by using generic references to terrorists and militants to employing a more specific, individualized reference to ISIL, the Islamic State of Iraq and Levant. Accordingly, the construction of the rebels is performed within a particular ideological frame, which aims to amplify the danger of the rebels and implicitly legitimize mass killings among the civilians. The most frequent lexical clusters associated with ISIL are identified as follows.

The patterns created by the prepositional phrases in Figure 5 yield no clear references by themselves. However, the concordance lines of the first two most frequent lexical clusters are demonstrated below.

The concordances in Figure 6 reveal that ISIL is depicted as the target of the Syrian and Russian military airstrikes, which hit and destroyed the main strongholds of ISIL. The concordances also show the areas where ISIL are located, such as Raqqa, Homs and Aleppo, where Aleppo and Homs are among the

\begin{tabular}{|c|c|c|c|}
\hline $\begin{array}{l}\text { Total No } \\
\text { Rank }\end{array}$ & $\begin{array}{l}\text { of Clust } \\
\text { Freq }\end{array}$ & $\begin{array}{l}\text { Types } \\
\text { Range }\end{array}$ & Total No. of Cluster Tokens \\
\hline 1 & 274 & 162 & of the isil \\
\hline 2 & 226 & 173 & the levant (isil \\
\hline 3 & 137 & 92 & against the isil \\
\hline 4 & 104 & 75 & that the isil \\
\hline 5 & 86 & 68 & by the isil \\
\hline 6 & 57 & 47 & with the isil \\
\hline 7 & 52 & 45 & from the isil \\
\hline 8 & 51 & 44 & and the isil \\
\hline 9 & 39 & 35 & to the isil \\
\hline 10 & 36 & 30 & country. the isil \\
\hline 11 & 33 & 23 & targeted the isil \\
\hline 12 & 31 & 27 & on the isil \\
\hline 13 & 27 & 24 & between the isil \\
\hline 14 & 27 & 22 & number of isil \\
\hline 15 & 23 & 21 & tens of isil \\
\hline
\end{tabular}

Figure 5: Three-word clusters of ISIL. 


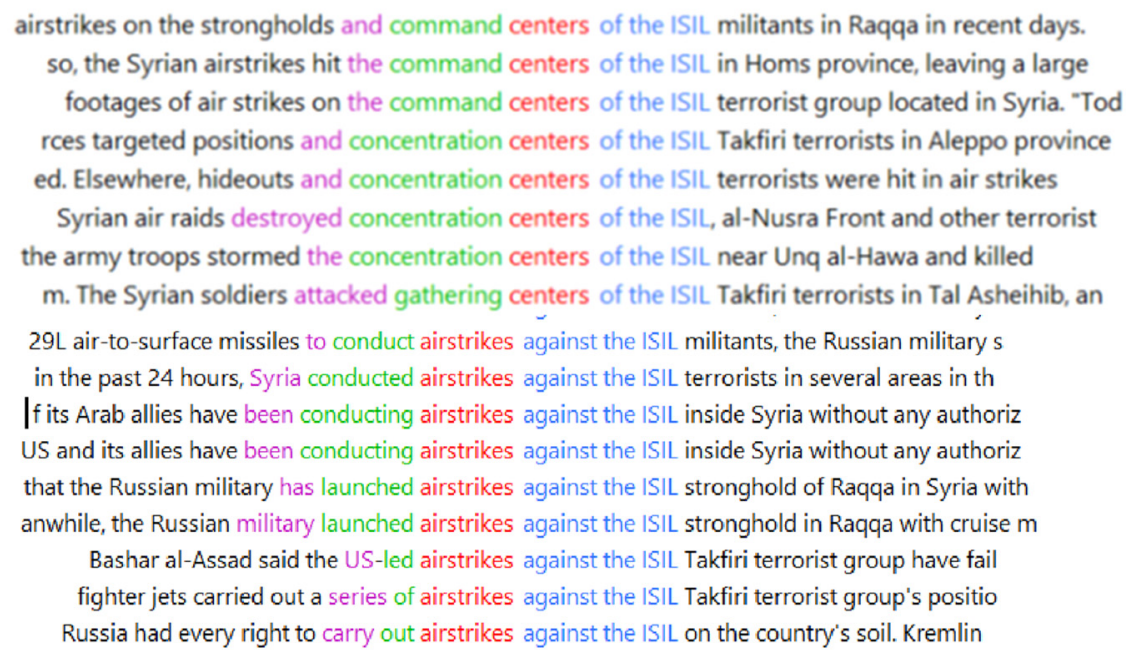

Figure 6: The concordances for of the ISIL and against the ISIL patterns.

three largest cities in Syria. This representation highlights the dominance of ISIL and its danger. It also positively foregrounds the government forces' operations to block ISIL's expansion. Along the same line, Fars' reports represent ISIL as the agent of criminal and brutal actions throughout the pattern of that the ISIL (see Figure 7). It is worth noting that the two keywords ISIL and terrorists appear to be used interchangeably. However, terrorists can be said to be an elastic term, which represents any act against the government regardless of whether the act is undertaken to defend citizens or protect the rebels' areas and families from the offensive of the government army or not. Therefore, the negativity toward the rebels in the reports is evident in the use of negative referential names and the allocation of the anti-government fighters to criminal activities, such as seizing more areas from the locals, launching shells against cities and executing their fighters who have defected from their affiliations (lines 12, 13, 14 and 62) in the concordances in Figure 7.

Another important aspect of the representation of the anti-government fighters is the negative stereotyping of the armed groups battling against the government. This depiction was elucidated through an investigation of the concordances of ISIL terrorist and as well as the pattern of ISIL and the while checking the left side of the concordances in Figure 8.

The concordances show a number of anti-authority powers fighting against ISIL; such as the Kurdish fighters, the Free Syrian Army, Al-Nusra Front and the Islamic Front. It is worth noting that the FSA and the Kurdish fighters are coupled with ISIL as illegal armed groups. Nevertheless, the FSA and the Kurdish fighters are the two legal armed units in Syria, which have international recognition. According to Janaby (2015, p. 182), the UN Security Council stated that FSA adheres to international law and human rights rules in military operations against the aggressive attacks of terrorists and government forces.

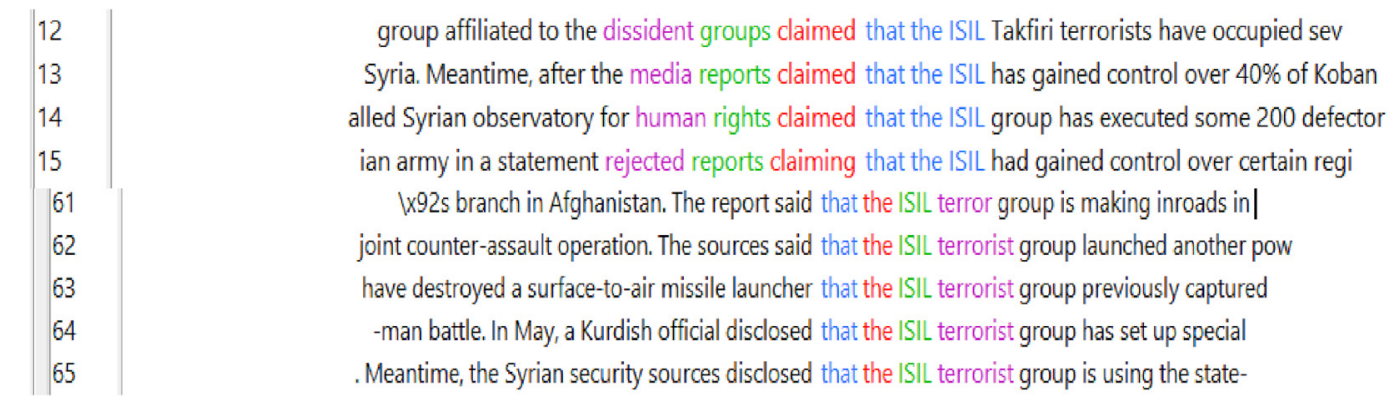

Figure 7: Concordances of that the terrorists. 


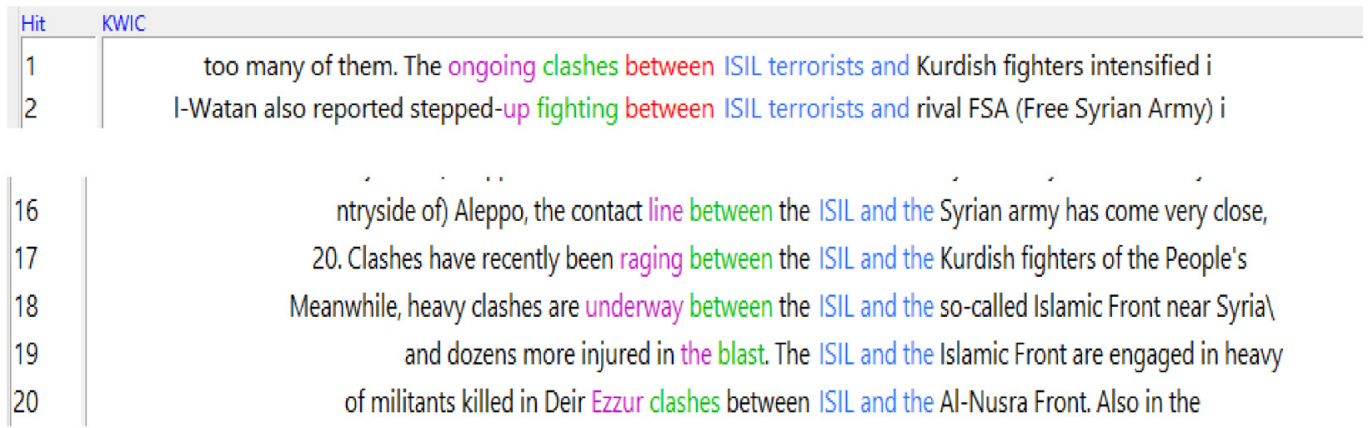

Figure 8: Concordances of ISIL terrorists and; ISIL and the.

Compared to the previous patterns of the terrorist and militant keywords, ISIL has been nominated as the perpetrators and the committers of war crimes. The numerous patterns that ISIL is associated with are all dedicated to identifying ISIL in relation to their violations of international law and extreme brutal actions, such as kidnapping, killing, stealing natural resources of gas and oil, smuggling foreign fighters and causing unrest with the support of the US and the Arabian Gulf countries.

\subsection{Takfiri}

Thematically, Takfiri explicitly denotes an extreme religious movement. This concept legitimizes excommunicating political leaders, governors and ordinary Muslims and defends sentencing them to death (Eikmeier 2007). Therefore, the use of this lexical choice to identify the anti-government SAs is ideologically motivated. It first frames the rebels in relation to the hostile Takfiri stance against moderate Muslims who do not strictly adhere to the Islamic teachings, thus threatening the security of Muslim communities in general. Secondly, Takfiri ideology rejects all of the manifestations of Westernization, liberalism and the concept of democracy, considering them an indication of relegation to apostasy (Pieri and Zenn 2016). Accordingly, framing the rebels within Takfirism informs two semantic macrostructures: religious radicalism and anti-West (Figure 9).

The concordances show that the anti-government fighters are described as Takfiri armed groups sent to Syria by Saudi Arabia and supported by the United States in lines 122 and 123. They are also linked to havoc in Arab countries (line 12), the terrorist act undertaken in Paris (line 16) and are affiliated to alQaeda in line 17. This depiction serves to ideologize the revolution, representing it as a planned plot to

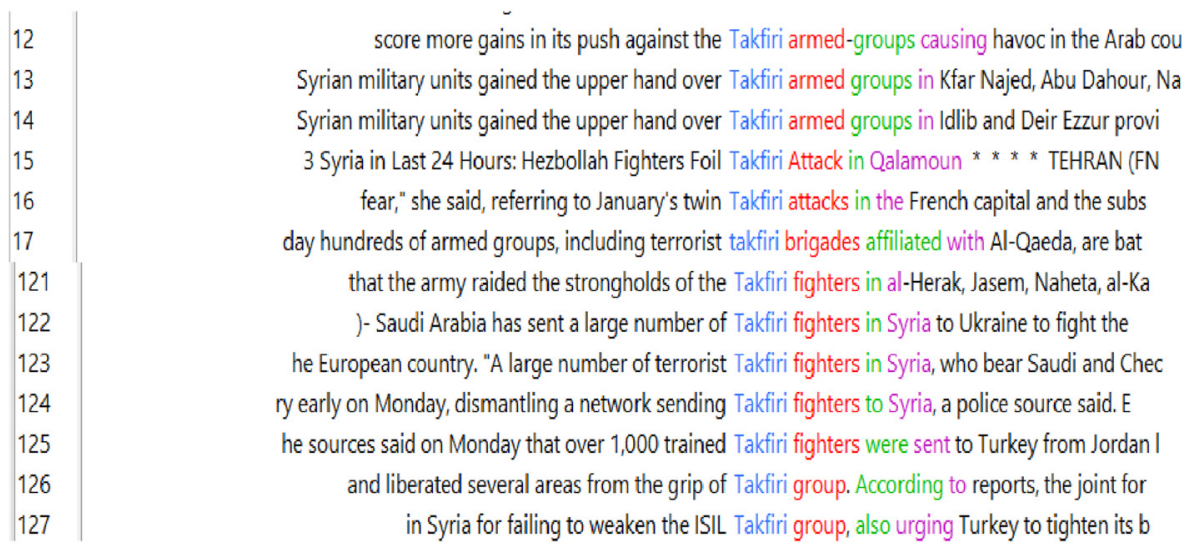

Figure 9: Concordance lines of Takfiri. 
overthrow the Syrian government. The reports also recall the twin Takfiri attacks in France, thus placing this group in challenge with the Western society.

These recurrent negative patterns, within which the opposition fighters are framed, serve to prime the concept of radicalism. Baker (2006) suggested the notion of an "incremental effect of discourse," stating that "a single word, phrase or grammatical construction on its own may suggest the existence of a discourse" (p. 13). Thus, by looking at the common lexical patterns of the anti-government fighters, one can conclude that they are represented as religiously violent hardliners. Moreover, the concordance analysis reveals that the linguistic environment in which extremists' pattern is situated repeatedly correlates the existence of Takfiri extremists with the act of support given by the United States. The following example is representative.

As the foreign-backed insurgency in Syria continues without an end in sight, the US government has boosted its political and military support to Takfiri extremists. Washington has remained indifferent to warnings by Russia and other world powers about the consequences of arming militant groups (“Senior MP: US War," August 30, 2013).

This extract shows an associative relation pattern, i.e. "word use relation rather than semantic lexical relation" (Ferrand and New 2003, p. 26), formed by linking the US government to Takfiri extremists. This sort of priming, according to psycholinguists, enhances memory recovery of the concept delivered by the recurrent use of a specific lexical pattern (McNamara 2005). Thus, whenever the US support in the Syrian conflict is mentioned the Takfiri fighters are recalled. This type of lexical associative priming is more pertinent to discourse prosody, as it conveys the sort of pragmatic references that insinuate the existence of a foreign conspiracy behind the revolt. On the other hand, checking the concordances of the Takfiri militants and Takfiri terrorists indicates the prevalence of the geographical places' patterns in representing the armed Takfiri group (Figure 10).

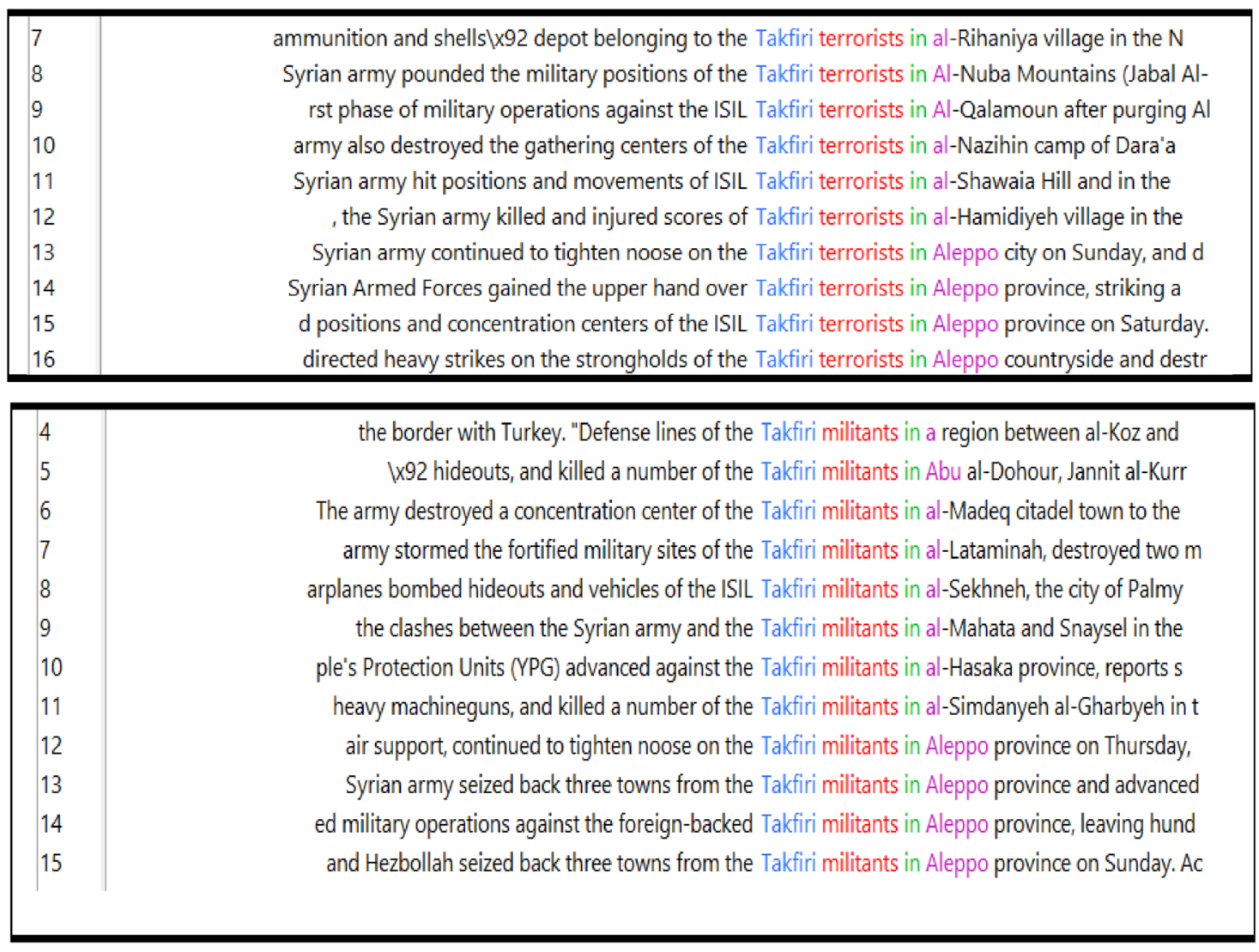

Figure 10: Concordance lines of the patterns Takfiri terrorists and Takfiri militants. 
The two sets of concordances illustrate the spread of Takfiris across several important places in Syria, such as al-Qalamoun, a strategic city and al-Hasaka, which witnessed battles between the Kurdish armed groups, the YPG and the government forces. The two cities are inclusively inhabited by the Sunni sect. In addition, the concordances show a recurrent reference to Aleppo province, which is the cradle of the Sunni population and the largest city in Syria (see lines 13, 14, 15 and 16). The left concordances, however, concern the government's military operations against Takfiri groups. Thus, in this pattern, the Takfiri rebels are represented in relation to the places populated by the Sunni faction.

The last keyword representing the anti-government SAs, namely groups see Table 1, appears to be a node that is pre-modified by all the previous keywords for terrorists, militants and Takfiri. Therefore, this keyword offers no additional references or significance in terms of representing the anti-government fighters.

\section{Summary of findings}

Our analysis of media bias in the coverage of the Syrian revolution in an Iranian news agency revealed a clear influence of Iran's political perspective. The coverage is characterized by suppressing the main representative voices of the rebels, who hold a moderate secular ideology, such as the Opposition and the FSA, while foregrounding, instead, the two radical ideologies of Salafi Jihadism and Islamism represented by ISIL, Takfiri and Jabhat al-Nusra. This finding of polarized discourse echoes van Dijk's (1998) ideological dichotomy of the positive-Self and negative other representation. The polarized representation of Fars at this micro-linguistic level, which revealed the exclusion of moderate rebels and the opposition as well as the overuse of value-laden and ideologically based lexical items to describe the anti-government fighters aligns with Wurth-Hough's (1983) results, who found that biased news is always selective, works to marginalize events and foreground others according to the preference of power holders.

Fowler's (1991, p. 12) proposed that "altering the economic base on which the media are grounded" serves to produce a more objective representation. This is because being independent financially would emancipate the news outlet from any outside interference that power holders may practice over the media. In contrast to this view, the current findings reveal that despite being a non-affiliated state news agency, Fars' framing of the opposition is propagandistic and reflects to a great extent the most important facet of Iran's foreign policy, which is characterized by an anti-Western perspective that stands against any kind of Western or American interference in the region (Khosravi Nik 2015). Therefore, the portrayal is conveyed as a Western conspiracy, where the role of the moderate Syrian rebels is greatly marginalized. This conclusion is in line with Bartley and Hidalgo-Tenorio's (2015) findings that media disseminate and sell the ideology of power holders and government lobbies; hence, Fars news conforms with the Iranian government's political position towards the Syrian revolution.

In addition, Fars excluded the two major globally acknowledged bodies that represent the Syrian rebels: the opposition and the FSA. It also excluded the identity of rebels, i.e. the Sunnis, who constituted the majority of the Syrian community (see Figure 1) and who led the revolution against the current government. This representation echoes the idea of the "preferred model" wherein the identification of participants, the selection of news stories and the structure of events are reported in a way that supports the "interests of the elites," i.e. the message that Iranian Fars intended for its readers (Van Dijk 1995, p. 14). In turn, these strategies served to hide the reality of the sectarian war against the Sunni community in Syria and legitimized the army's violence against the rebels who were being represented as terrorists. This reality has been glimpsed by linking the demographic distribution of the Syrian community (see Section 2) to the battled areas shown in the concordance analysis. To give an example, al-Qalamoun and Hasaka, where the intensive military actions of the government forces were taking place (see Figure 8) are Sunnis populated areas. 


\section{Conclusion}

The overall framework of the analysis aimed to relate the discursive practices of Fars news agency to the social and political practices that motivated the resulting representations. Considering the fact that discourse is "a circular process in which social practices influence texts, via shaping the context and mode in which they are produced" (Richardson 2007, p. 37), the sociopolitical context of this incident can be drawn upon in revealing the ideological implications behind the biased discursive practices, i.e. stereotyping, exclusion, omission and so on.

This study has demonstrated how the opposition of the Syrian government was represented in the coverage of Fars news agency through examining the semantic macrostructures, keywords, lexical associations and inspecting their concordance patterns. Findings indicate that the political perspective of Iran was clearly influential for Fars' coverage of the Syrian revolution. It focused on the terrorist armed groups at the expense of the legal opposition fronts in the conflict resulting in a bias in the representation of the opposition. This polarized representation of Iranian Fars can be seen as the opposite of the Arab news coverage, such as Al-Arabia, Al-Jazeera and Arab news, which express the Sunni perspective (see Akkerhuis 2013, Amin and Jalilifar 2013). They all polarized the coverage in favour of the opposition front and the anti-government fighters, while Fars, representing the Shia mouthpiece, foregrounded the negativity of the opposition and enhanced the positive aspects of the Syrian government defence.

Fars used ideologically loaded keywords and lexical choices to identify the anti-government fighters. They were identified as terrorists, ISIL, al-Qaeda-linked, foreign-backed and Takfiri groups. Therefore, the overall picture of the Syrian conflict provided by Fars tends to depict an invasion instigated by the US and backed by the Arabian Gulf States, where the fighters are organized foreign-backed militias smuggled into Syria with the support of Turkey. Fars also depicted the civilians as being victimized, calling for Assad to defend them throughout the protest marches held against the militants.

Furthermore, thematically, the anti-government fighters were negatively framed within the semantic macrostructures of security threat, danger, brutality, anti-moderate Muslim and radicalism. Thus, the findings, as a whole, conform with van Dijk's (1996) view that "there is evidence that in many situations the news media have been persuaded, manipulated or even coerced to follow political (or military) views on international affairs" (p. 28). Accordingly, instead of more neutrally representing the conflict a civil uprising conducted against the government, Fars reported it in terms of Islamic conflict against foreignbacked ambitions in the Middle East, supported by the overuse of lexical choices such as ISIL, foreignbacked and terrorists and the exclusion of moderate rebels and opposition.

\section{References}

Afzal, N., and M. Harun. 2015. "A critical analysis of newspaper editorial discourse on the portrayal of uprising in Libya and Syria." Academic Research International 6(4): 243-54.

Akkerhuis, D. 2013. Western vs. Muslim media on the civil war in Syria. An empirical analysis of Huntington's Clash of Civilizations (Master's thesis, Utrecht University). Retrieved from https://dspace.library.uu.nl/handle/1874/283252.

Alharbi, A. 2012. Social Representations of 'IAM' in Two Australian Newspapers Before and After 9/11: A Tri-semantic Framework (Doctoral dissertation, Monash University).

Ali, M. A., and A. Omar. 2016. "Discourse and manipulation in the representation of the Russian military intervention in the Syrian Civil War." International Journal of Linguistics 8(3): 129-40.

Alsaleh, A. 2015. Voices of the Arab spring: Personal stories from the Arab revolutions. New York: Columbia University Press.

Amin, F., and A. Jalilifar. 2013. "The disourse of war in the Middle East: Analysis of Syria's civil crises in English editorials published in Iran, Turkey and Saudi Arabia." Journal of Teaching Language Skills 32(3): 1-21.

Anthony, L. 2014. AntConc (Version 3.2.1) [Computer Software]. Tokyo, Japan: AntLab. Retrieved from http://www.antlab.sci. waseda.ac.jp/.

Arimatsu, L., and Choudhury, M. 2014. The legal classification of the armed conflicts in Syria, Yemen and Libya. London: Chatham House. 
Asher-Schapiro, A. 2016, March 15. "The young men who started Syria's revolution speak about Daraa, where it all began." Vice News. Retrieved from https://news.vice.com/article/the-young-men-who-started-syrias-revolutionspeak-about-daraawhere-it-all-began.

Baker, P. 2006. Using corpora in discourse analysis. London: A\&C Black.

Baker, P., \& McEnery, T. (2005). A corpus-based approach to discourses of refugees and asylum seekers in UN and newspaper texts. Journal of Language and Politics 4(2): 197. doi: 10.1075/jlp.4.2.04bak

Baker, P., Gabrielatos, C., \& McEnery, T. (2012). Sketching Muslims: A corpus driven analysis of representations around the word 'Muslim' in British press 1998-2009. Applied Linguistics 34(3): 255-278.

Baker, P., Gabrielatos, C., \& McEnery, T. (2013). Discourse analysis and media attitudes: The representation of Islam in the British press. Cambridge: Cambridge University Press.

Bartley, L., and E. Hidalgo-Tenorio. 2015. "Constructing perceptions of sexual orientation: a corpus-based critical discourse analysis of transitivity in the Irish press." Estudios Irlandeses 10(10): 14-34.

Bass, S. 2016. "Syria's armed opposition: a spotlight on the 'moderates.' Small Arms Survey." Security Assessment in North Africa Dispatch No. 5. Retrieved from http://www.smallarmssurvey.org/sana/publications/listed-in-chronologicalorder.html.

Campanella, M. S. 2017. News media bias and the Syrian refugee crisis (Unpublished doctoral dissertation). James Madison University, Harrisonburg, VA.

Eikmeier, D. C. 2007. “Qutbism: An ideology of Islamic-Fascism.” Parameters, US Army War College Quarterly [PDF file], 85-97. Retrieved from https://apps.dtic.mil/dtic/tr/fulltext/u2/a485995.pdf.

Ferrand, L., and New, B. 2003. "Semantic and associative priming in the mental lexicon." In Mental Lexicon: Some Words to Talk About Words, ed. P. Bonin, 25-43. New York: Nova.

Fowler, R. 1991. Language in the News. London: Routledge.

Gelbart, J. 2010. “Iran-Syria axis: a critical investigation.” Stanford Journal of International Relations 12(1): 36-42.

Goldsmith, L. 2015. Cycle of fear: Syria's Alawites in war and peace. New York: Oxford University Press.

Goodarzi, J. M. 2013. "Syria and Iran: alliance cooperation in a changing regional environment." Middle Eastern Studies/ Ortadogu Etütleri 4(2): 31-54.

Janaby, M. 2015. The legal regime applicable to private military and security company personnel in armed conflicts. New York: Springer.

Khalifa, M. 2013. “The impossible partition of Syria.” Arab Reform Initiative. Retrieved from https://archives.arab-reform.net/ en/node/510.

Khosravi Nik, M. 2015. Discourse, identity and legitimacy: Self and other in representations of Iran's nuclear programme. Amsterdam: John Benjamins.

McNamara, T. P. 2005. Semantic priming: perspectives from memory and word recognition. New York: Taylor \& Francis Group.

Pantucci, A. B., and A. B. Tabrizi (eds). 2016. Understanding Iran's role in the Syrian conflict. London: Royal United Services Institute.

Pieri, Z. P., and J. Zenn. 2016. "The Boko Haram paradox: ethnicity, religion, and historical memory in pursuit of a caliphate." African Security 9(1): 66-88.

Porat, L. 2010. "The Syrian Muslim brotherhood and the Assad regime." Middle East Brief 47: 2-7.

Reisigl, M., and R. Wodak. 2001. Discourse and discrimination: rhetorics of racism and antisemitism. London: Routledge.

Richardson, J. (2004). (Mis)representing Islam: The racism and rhetoric of British broadsheet newspapers. Vol. 9. Amsterdam: John Benjamins.

Richardson, J. 2007. Analysing newspapers: an approach from critical discourse analysis. London: Palgrave.

Rodgers, L., D. Gritten, J. Offer, and P. Asare. 2016. "Syria: the story of the conflict." BBC News. Retrieved from http://www.bbc. co.uk/news/world-middle-east26116868.

Santaemilia, J., and S. Maruenda. 2014. "The linguistic representation of gender violence in (written) media discourse: The term 'woman' in Spanish contemporary newspapers." Journal of Language Aggression and Conflict 2(2): 249-73.

Scott, M., and C. Tribble. 2006. Textual patterns: keyword and corpus analysis in language education. Amsterdam: John Benjamins.

Shojaei, A., K. Youssefi, and H. S. Hosseini. 2013. "A CDA approach to the biased interpretation and representation of ideologically conflicting ideas in Western printed media." Journal of Language Teaching \& Research 4(4), 858-68.

Shrivastava, K. M. 2007. News agencies from pigeon to internet. Berkshire, UK: New Dawn Press.

Van Dijk, T. A. 1985. "Semantic discourse analysis." In Handbook of Discourse Analysis, Vol. 2, 103-36. London: Academic Press.

Van Dijk, T. 1995. "Power and the news media." In Political Communication in Action: States, Institutions, Movements, Audiences, ed. D. L. Paletz, 9-36. Cresskill, NJ: Hampton Press.

Van Dijk, T. A. 1996. Discourse studies: a multidisciplinary introduction. Vol. 2: Discourse as social interaction. London: SAGE. Van Dijk, T. A. 2013. News analysis: case studies of international and national news in the press. New York: Routledge. Wurth-Hough, S. 1983. "Network news coverage of terrorism: the early years." Studies in Conflict \& Terrorism 6(3): 403-21. 